\title{
粒度と食感からみた抹茶のおいしさ
}

\author{
沢村信 一 $^{\dagger}$
}

(2019年 9 月 6 日受理)

\section{The Mouthfeel of mactha from the Viewpoint of Particle Size and a Texture}

\author{
Shin-ichi Sawamura
}

和食が，日本の伝統的な食文化としてユネスコ無形文 化遺産に登録され，世界的に注目さるようになった。そ の和食とともに，抹茶も世界的に注目され，ブームを向 かえている。抹茶が注目されているのは, 深い緑色と濃 厚なうま味を有しており，さらに和食と同じょうに長い 歴史と文化を持っているからである。

抹茶は，本来の用途である茶の湯のみならず，種々の 加工食品の副原料として用いられる。桑原によれば，そ の比率は生産量の $95 \%$ 前後を占め, 本来の用途をはるか に上回っている1)。このような加工食品に用いられる抹 茶は, 茶臼以外の種々の装置で粉砕される場合がある。

抹茶の扔いしさは，味や香りにテクスチャーと呼ばれ る食感が加わったものであり，抹茶のテクスチャーを明 確に定義することは困難だが，本稿では粒度（中位径） を切り口として抹茶のテクスチャーについて考える。

\section{1. 食のおいしさ}

食の成分的なおいしさは，うま味や甘味成分が多いこ とによって表される。また, 食べ物のもつテクスチャー, コク味，香りなどもおいしさに関与している。食のおい しさは，単にうま味や甘味成分のみならず，食に関係す るあらゆるものに関連している。茶の湯においても, 茶 会や茶室で飲む抹茶と家庭で飲む抹茶では，たとえ同じ ものでも感じ方がまったく違ってくる。

茶の扔いしさは, うま味成分であるアミノ酸と, 渋味 成分のカテキン類, および苦味成分のカフェインのバラ
ンスで表される。苦味成分であるカフェインは, 通常飲 用される煎茶では, 茶の種類や摘採時期などにあまり影 響されずにほぼ一定である。渋味成分のカテキン類は, 抹茶や玉露といった高級な茶では若干少なく, 煎茶, 特 に番茶ではすこし多い。抹茶や玉露あるいは新茶などの 高級な茶の扔いしさは, アミノ酸が多いことによって, うま味が強いことが重要である。これに対して, 煎茶は 適度なうま味と苦渋味によって口腔内をすっきりさせる ことで, おいしいと感じる。さらに抹茶は, 安心感やリ ラックスを感じさせる濃い緑色をしており, 口に含むと アミノ酸によるうま味と濃厚な質感と滑らかさを感じる ことで，さらにおいしいと感じることができる。

食感に関しては，通常は茶臼で粉砕した抹茶を飲む機 会しかないが, 茶臼以外の装置（ボールミルなど）で粉 砕した抹茶注1) を飲用すると, ざらつきを感じることが ある。そのざらつきを感じる抹茶の粒度を測定すると, 茶臼で粉砕したざらつきを感じない抹茶と, 中位径で比 較するとほぼ同じであった。本稿においては, 同等の碾 茶を用い, 種々の装置で粉砕した抹茶の粒度とその食感, さらにこれまで得られている論文等から種々の食品の粒 度を比較することで, 粒度と食感からみた抹茶の扔いし さに関して考察した。

使用した抹茶はすべて茶の湯の練習用に用いるレベル の碾茶を用い, 茶臼・ボールミル・ジェットミルを用い て粉砕した。それぞれの装置で粉砕した抹茶を, ここで は茶臼抹茶, ボールミル抹茶, ジェットミル抹茶とする。 さらにボールミル抹茶は気流式分級機を用いて, 粒度

Corresponding author : awaji@gem.bekkoame.ne.jp

注 1 日本茶業中央会では，抹茶の定義を「碾茶（覆下栽培した茶葉を碾茶炉等で揉まずに乾燥したもの）を茶臼等で微粉末状に製造したもの」とし ているが, 本稿では, 茶臼以外の装置を用いて粉砕した碾茶を含めて抹茶として扱う。 
$10 \mu \mathrm{m}$ を境として分級し, 粒度の粗い分画を粗粉抹茶, 微細な分画を微粉抹茶とした。茶臼は, 電動回転式花崗 岩製のものを用いた。ボールミル粉砕機は, ドラム缶を 横にしたよう形状であり，その中へ直径約 $50 \mathrm{~mm}$ のセ ラミックボールをいれ，回転することによってボール同 士が当たる衝撃によって, 碾茶が粉砕される。ジェット ミル粉砕機は, 超高速の空気を送り込むことで, 碾茶同 士が衝突し, 粉砕される装置である ${ }^{2)} 。$

加工食品用の抹茶を茶臼以外の装置で粉砕する理由 は, ボールミルの場合は単位時間当たりの粉砕量の多さ, ジェットミルの場合は茶臼によって粉砕された抹茶より 微細に粉砕されるからである。微細に粉砕された抹茶は, 起泡性に優れ, 泡沫が細かくなるなどの特徵を有してい る $^{3)}$ 。

\section{2. 機械刺激受容体}

口腔内において食品の大きさや硬さを認識し, 咀嚼に フィードバックを行ない, 食べ物を讌下へ誘導させるの は，機械刺激受容体が関与しているといわれる。口腔内 には，このほかに基本五味の受容体や，温度刺激受容体 があり，食べ物に含まれる成分を受容することでおいし いと感じたり，腐敗したものや異物を拒絶したりする。

食におけるざらつき感は「テクスチャー」という言葉 で表される。テクスチャーは, 硬さ・凝集性・もろさ・ 粘性・弾力性の機械的特性と, 滑らかさやざらつきを感 じ，粒子の大きさと形などの幾何学的特性で表される。 食品のざらつき感に関しては, 多くの先行研究があるが, 粒度の測定法が統一されておらず，それぞれの研究相互 の比較検討がむずかしい。例えば，篩分けした目開きを 粒度としたり，他の測定法や最大粒度を用いたりした例 がみられる。粒度が $1 \mu \mathrm{m}$ 前後の粒子の測定は, レーザ 一回折式粒度分布測定装置が開発されて以降, それ以前 の測定法で計ったものは，得られる粒度に関する值が異 なり比較できない。

粒度とざらつき感が確認されている事例として, チョ コレートがあげられる ${ }^{4,5)}$ 。ざらつきを感じないための 中位径は25～35 $\mu \mathrm{m}$ 以下であった。別の試験では, 最大 粒径 $13 \mu \mathrm{m}$ であれば, ごくわずかな人にしかざらつきを 感知できないとしている。また, 国内で生産されている ココアの中位径は $30 \mu \mathrm{m}$ 程度であるが，ヨーロッパで生 産されているココアの中位径は $20 \mu \mathrm{m}$ 以下である。人に よっては国産のココアにざらつきを感じ, ヨーロッパ産
のものを滑らかと感じる。

今井によると, 食品のなかには, 小豆餜・マッシュポ テト・すりゴマなどのようにざらつき感がおいしさの重 要因子となっているものと, チョコレート・ココア飲料・ バターなどのようにざらつき感が好ましくないものがあ $ろ^{4)}$ 。ざらつき感を好ましいとするのは, 経験的な慣れ による好みであると考える。通常の技術では, より細か く粉砕できないものは, そのざらつき感に慣れることに よって, 新たに同じ食材で滑らかなものに出会ったとき に, 異質なものとして好ましくないと感じてしまう傾向 がある。ざらつき感は, 粒度が大きいことを意味し, 滑 らかさを求めるのが本来であるが, 経験や慣れによって, 一部の食品において, そのざらつき感を好ましいと感じ てしまう。

これらの事例から, 口腔内でざらつきを感じるのは中 位径20３0 $\mu \mathrm{m}$ を境界として，それ以上の中位径である とざらつき感があり, それ以下であると滑らかと感じ る。このざらつき感は, 粉体の濃度によって異なり,さ らに年齢によって徐々に感度が低下することが知られて いる。

\section{3. 粉体の粒度}

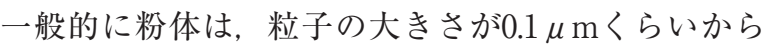
$1 \mathrm{~mm}$ 程度と幅が広く, かつ粒子自体が非常に小さく, また量が多いため, その粒度を測定する方法が種々開発 されてきた。レーザー回折式粒度分布測定装置注2) で抹 茶を測定した場合の, 一次元（個数基準）と三次元（体 積基準）の粒度分布 ${ }^{6)}$ と累積積算頻度分布を図 1 に示 す。茶臼抹茶とジェットミル抹茶を体積基準で表した中 位径は，それぞれ $18.3 \mu \mathrm{m}$ と $2.9 \mu \mathrm{m}$ であった。また，そ れぞれを個数基準における中位径は, それぞれ $0.74 \mu \mathrm{m}$ と0.99 $\mu \mathrm{m}$ であった注3)。抹茶の場合は, 電子顕微鏡か ら得られた画像などを見ると, 個数基準で表したように $1 \mu \mathrm{m}$ 程度の粒子が大多数を占める ${ }^{7)}$ 。抹茶は粒度分布 域が広いため, 存在比率では少ないものの大きな粒子が 存在し, その粒子が体積基準において物性に大きな影響 を与える。例えば $1 \mu \mathrm{m}$ の粒子と $10 \mu \mathrm{m}$ の粒子では, 粒 径は10倍の違いであるが, 体積は1000倍の違いとなるよ うに, 大きな粒子は体積でみた場合, 粉体全体の粒度分 布に大きな影響を及ぼす。小麦粉などの粉体に異物があ ると, 指先で触ると感じるが, 小麦粉粒子全体に対する 異物粒子の割合は非常に少ない。しかし, 指先の触感は,

注 2 レーザー回折散乱光式粒度分布測定装置に関しては,「島津製作所HP＼cjkstart粉博士」のページに詳しい。 http://www.an.shimadzu.co.jp/powder/lecture/index.htm

注 3 抹茶関係者の間では，抹茶の粒度が約1マイクロメートルであるという話を聞くことがあるが，これは個数基準つまり見た目による值が流布し た結果である。 
体積基準

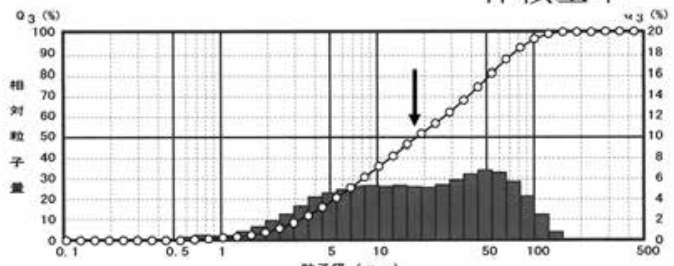

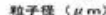

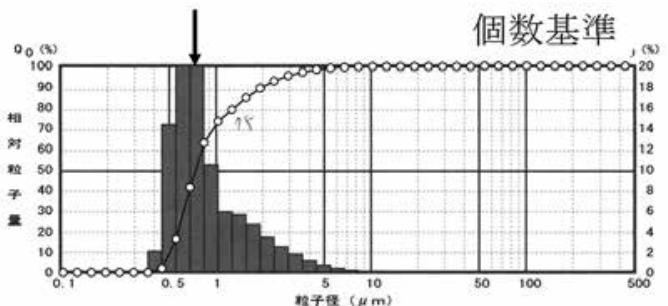

ボールミル抹茶
体積基準

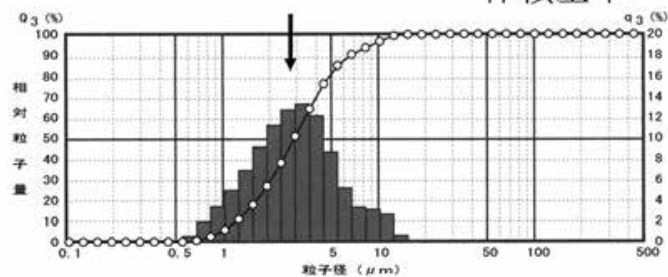

個数基準

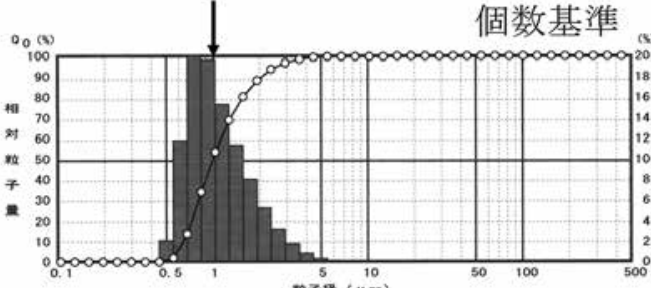

ジェットミル抹茶

図 1.レーザー回折式粒度分布測定装置による粒度測定

(体積基準と個数基準の違い)

左上：体積基準による茶臼抹茶（中位径： $18.3 \mu \mathrm{m}$ ), 左下：個数基準による茶臼抹茶（中位径：0.74 $\mu \mathrm{m}$ )

右下：体積基準によるジェットミル抹茶（中位径： $2.9 \mu \mathrm{m}$ ), 右下：個数基準によるジェットミル抹茶（中位径：0.99 $\mu \mathrm{m}$ ) *矢印 $(\rightarrow)$ は, 中位径を示す。

異物感があることでずいぶん異なり，小麦粉の粒度を実 際より大きなものと認識し, 大きな粒子の割合は小さい が, ざらついた粉と感じるのはこのためである。以上の ような理由から粉体の物性評価には一般的に体積基準で 表される中位径を用いる。

\section{4. 抹茶の粒度とおいしさ}

今回使用した抹茶の粒度分布を図 2 に示す。ここに示 したものは，茶臼抹茶（左上図）とボールミル抹茶（左 下図)，そしてボールミル抹茶を用いて $10 \mu \mathrm{m}$ を境とし て気流式分級機で分級した粗粉（右上図）および微粉抹 茶（右下図）である。ジェットミル抹茶は，微粉抹茶と 同じような粒度分布を示すため省略した。碾茶を茶臼や ボールミルで粉砕すると粒度分布が二峰性を示した。細 かい粒度域のピークは，茶葉の薄いところが粉砕された もの, 粗い粒度域のピークは茶葉の硬いところ, すなわ ち葉脈部分や茶葉の厚いところが粉砕されたものと考え る。そして茶臼抹茶とボールミル抹茶を比較すると, こ の 2 つピークの比率が異なり, 茶臼で粉砕した抹茶の 方が細かい粒度域のピークが，ボールミル抹茶より多く なった。また，分級して調整した微粉抹茶と粗粉抹茶の それぞれのピークは，元のボールミル抹茶の大小の粒度 域に相当する。茶臼で粉砕した場合, 二峰性の粗い分画 はピークとしてほとんど認識されない場合もあるが，広
い粒度域を維持している。

茶臼抹茶とボールミル抹茶の中位径は, それぞれ $18 \mu \mathrm{m}$ であり，ボールミル抹茶を分級した粗粉抹茶は $19 \mu \mathrm{m}$, 微粉抹茶は $5 \mu \mathrm{m}$ であった。粗粉抹茶は, 複数回の試験 の結果では中位径20３0 $\mu \mathrm{m}$ を示した。デー夕は示さな いがジェットミル抹茶の中位径は $3 \mu \mathrm{m}$ であった。

ジェットミル抹茶を加えた 5 種類の抹茶の中位径を二 峰性と粒度面からまとめると以下のようになる。

茶臼抹茶：二峰性を示す細かい粒度域のピーク比率が 大きい。中位径10～20 $\mu \mathrm{m}$ を示す。

ボールミル抹茶：二峰性を示す粗い粒度域のピーク比 率が大きい。中位径10～20 $\mu$ mを示す。

粗粉抹茶：ボールミル抹茶の細かい粒度域のピークが 存在しない。中位径20～30 $\mu \mathrm{m}$ を示す。

微粉抹茶 : ボールミル抹茶の粗い粒度域のピークが存 在しない。中位径 5 〜 $10 \mu \mathrm{m}$ を示す

ジェットミル抹茶 : 粗い粒度域のピークがない。中位 径 3〜 $5 \mu \mathrm{m}$ を示す。

このように，同じ規格の原料碾茶を種々の装置で粉砕 した場合，同じょうな中位径を示しても，得られた抹茶 の粒度分布が異なっている場合がある。その理由は, 中 位径が累積積算分布の50\%值から算出しているためであ る。粒度分布様式が異なる要因は, それぞれの装置の粉 砕応力の違いによる。それぞれの装置内において, 種々 の応力が働いているが，それぞれの装置における粉砕応 


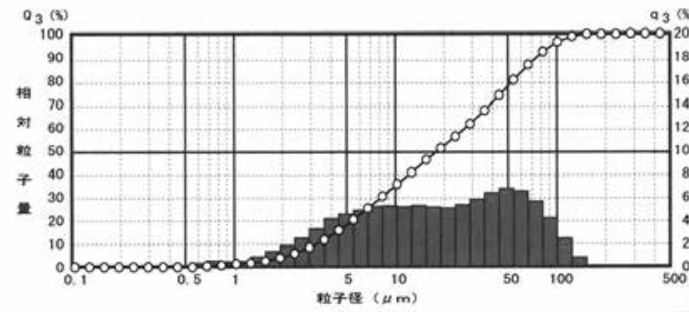

茶臼抹茶 $\quad(18 \mu \mathrm{m})$

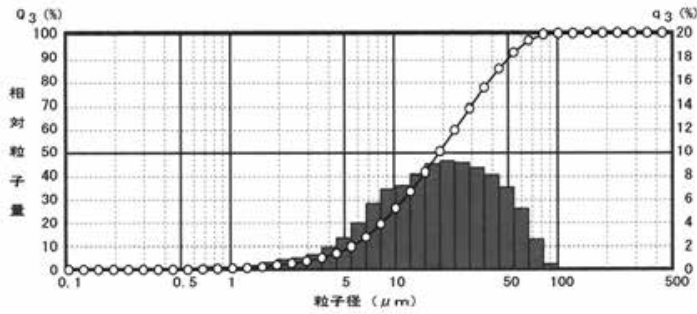

粗粉抹茶 $\quad(19 \mu \mathrm{m})$

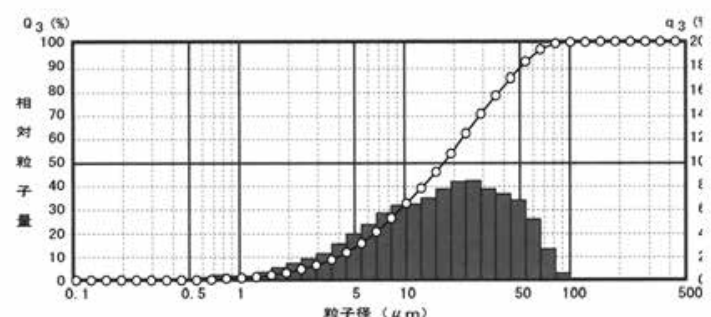

ボールミル抹茶 $\quad(18 \mu \mathrm{m})$

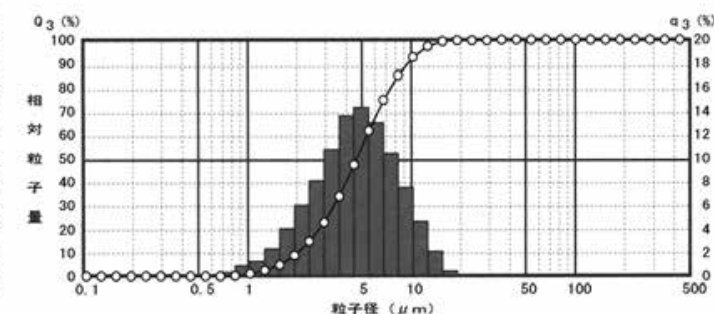

微粉抹茶 $(5 \mu \mathrm{m})$

図 2. 各種抹茶の粒度分布の違い（茶臼抹茶，ボールミル抹茶，粗粉抹茶，微粉抹茶）

力は異なり，その結果として円形度注4) などの違いとし て表される ${ }^{6)}$ 。

各々の抹茶の官能評価における食感は, 以下のようで あった。官能評価は，3〜 5 人で複数回実施し，パネル 間で評価結果に相違はなかった。官能評価の方法は, 2 グラムの抹茶を秤量し，熱湯 $80 \mathrm{~mL}$ 加えて，電動式の 茶筅で十分擋拌したのち，飲用した。

茶臼抹茶：質感があり，滑らか。

ボールミル抹茶：少しざらつきを感じるが滑らか。

粗粉抹茶：ざらつきを感じる。

微粉抹茶:さらっとしている, 非常に滑らか。水っぽい。 ジェットミル抹茶:さらっとしている, 非常に滑らか。 水っぽい。

表 1 に，調整した各種抹茶の粒度（中位径）と官能評 価の結果をまとめた。

茶臼・ボールミル・粗粉の各抹茶の中位径は, ほとん ど同じであるが，官能評価の結果は，異なった。口腔内 におけるざらつき感は，基本的には中位径に拠るが，中

表 1. 各種抹茶の粒度と官能評価結果

\begin{tabular}{|c|c|c|}
\hline & 中位径 & 食 感 \\
\hline 茶臼抹茶 & 18 & 質感がありなめらか \\
\hline ボールミル抹茶 & 18 & 少しざらつきを感じるがなめらか \\
\hline 粗粉抹茶 & 19 & ざらつきを感じる \\
\hline 微粉抹茶 & 5 & さらっと・なめらか \\
\hline ジェットミル抹茶 & 3 & (水っぽい) \\
\hline
\end{tabular}

位径は，累積積算頻度分布の $50 \%$ を示すため，各々の抹 茶の分布域までは考慮されていない。同じ等級の原料を 種々の装置で粉砕し, 同じような中位径を示す抹茶であ っても, 粒度分布の違い（二峰性の比率の違いや最大 值（90\%径）など）によって，官能評価の結果が異なっ たものと考察した。たとえ中位径がざらつきを感じない $20 \mu \mathrm{m}$ 以下であっても，最大值（90\%径）が100 $\mu \mathrm{m}$ 超える場合はざらつきを感じる場合がある。今回用いた 各抹茶では, $100 \mu \mathrm{m}$ を超える大きな粒子によるざらつ き感の差異は感じられなかった。抹茶の中位径および粒 度分布域が，ちょうど口腔内の機械刺激受容体のざらつ きを感じる境界域であるため, このような結果となった と考える。

抹茶のように粒度域が広く, 粒度分布が異なるが同じ ような中位径を示す粉体の物性を評価する場合は, 中位 径に加えて, 最大值（累積積算頻度分布 $90 \%$ 值）や均一 度 (累積積算頻度分布 (10\%值)/(60\%值)）などの指標 も重要な因子と考える（表 2 ）。

\section{表 2．粉体の粒度評価にもちいる用語と解説}

\begin{tabular}{|l|l|}
\hline 中位径 & 累積積算分布 $50 \%$ 値 \\
\hline 最大值 & 累積積算分布 $90 \%$ 值（場合によっては $95 \%$ 値） \\
\hline 最小值 & 累積積算分布 $10 \%$ 值（場合によっては $5 \%$ 值） \\
\hline 均一度 & 累積積算分布（10\%值/60\%值） \\
& $*$ 最小值は, 本稿では使用しないが参考のため記載した。
\end{tabular}

注 4 円形度は，「あるものの形が，どれだけ円に近いか」を表す指標であり $\left(4 \pi \times\right.$ 面積 $\left./(\text { 周囲長 })^{2}\right)$ で計算される。真円に抽 1 となり，図 形が複雑になるほど值は小さくなる。 


\section{5.まとめ}

抹茶は，濃い緑色と強いうま味によっておいしいと感 じて飲むことができる。今回, 種々の装置を用いて粉砕 した抹茶を飲用したところ，ほぼ同じ中位径を示すにも かかわらず，官能評価では食感が異なり，結果として粒 度面からおいしくない場合が認められた。

口腔内には機械刺激受容体が存在し, 食べ物の大小・ 硬軟・形状などを受容し, 咀嚼の程度や䜩下に適してい るかを判断している。この機械刺激受容体によるざらつ きを感じる粒度の境界は, 種々の食品の粒度と食感によ る研究成果から中位径 $20 \sim 30 \mu \mathrm{m}$ とされている。茶臼や ボールミルで粉砕した抹茶の粒度の中位径は, このざら つきの境界とされている $20 \mu \mathrm{m}$ 程度である。抹茶の場合, 小さな粒子は $1 \mu \mathrm{m}$ 程度から大きなものは数十 $\mu \mathrm{m}$ まで と粒度域が広く, さらに粒度分布が二峰性を示し, その 二つのピークの比率が粉砕装置の種類によって異なる。 この抹茶のもつ粒度域の広さと二峰性のピークの比率に よって, 茶臼抹茶は質感や濃厚感があり, かつ滑らかに 飲用することができ，一方でボールミル抹茶はすこしざ らつきを感じ, 粗粉抹茶はざらつきを強く感じるという 食感面による違いが現れる。また, 微粉抹茶やジェット ミル抹茶は, ざらつき感がなく, 非常に滑らかであるが, 茶臼抹茶の持つ濃厚な質感にそしく水っぽいと感じる。 これは，広い粒度域を有していないためと考える。

このように茶臼で粉砕した抹茶は, 濃厚な質感と滑ら かさを併せ持っているが, 他の装置で粉砕した抹茶は, 同じ中位径を示す場合でも同じような食感を得られるわ けではなく，ざらつきを感じたり，ものたりなく水っぽ さを感じたりする。結果論ではあるが，ボールミルやジ エットミルという近代的で粉砕速度が速い装置と比較し て，茶臼という伝統的な粉砕道具を用いて挽いた抹茶が 粒度面からみてもおいしいと感じることができるのは, 興味深いことである。

本稿の内容は，平成28年度茶の湯文化学会大会におい て発表したものを編集したものである。
6. 摘 要

本稿では, 同じレベルの碾茶を茶臼・ボールミル・ジ エットミルなどの粉砕機によって粉砕した抹茶を用い て, レーザー解析式粒度分布測定装置で中位径を測定し た。また，それぞれの抹茶の官能評価を実施し，抹茶の 粒度の違いからくる食感によるおいしさに関して考察し た。

茶の湯で使用される抹茶は, 碾茶を茶臼で粉砕するた め粒度に大きな違いがないが, 食品加工用の抹茶は種々 の粉砕機によって粉砕される。茶臼で粉砕した抹茶は広 い粒度域を持ち, 中位径は10〜20 $\mu \mathrm{m}$ である。食品加工 用として一般的に使用されるボールミル抹茶の中位径 は，茶曰で粉砕したものとほぼ同じである。ジェットミ ル抹茶や気流式分級機で分級した微粉抹茶は, 中位径 3〜 $5 \mu \mathrm{m}$ と微細であった。

茶臼抹茶と, ボールミル抹茶では, 中位径はほぼ同じ であるが，その粒度分布様式が異なり，ボールミル抹茶 にざらつきを感じる場合がある。また，分級によって得 られた微粉抹茶は, さらっとしており質感を感じない。

古くから使われてきた茶臼で粉砕した抹茶は, 結果と して質感となめらかさを合わせ持っており，飲んだとき に食感としておいしさを感じることができる。

\section{7. 引用文献}

1 ）桑原秀樹 (2015): 第1章 抹茶の基本 抹茶の生産量と碾茶生産 量の不思議. 桑原秀樹 (2015)「㧍抹茶のすべて」, 誠文堂新光社, pp.10-11.

2 ）沢村信一・原口康弘: 粉末茶葉の凝集抑制方法, 特許第5 485678 号 (特願2009-288761) 2009年12月21日出願

3 ) 沢村信一・一谷正巳·池田博子·園田純子 (2012): 粒度の異なる 抹茶の起泡性と泡沫径, 食科工, 59, 109-114.

4 ) 今井悦子 (2011) :ざらつき感の定量化, ハイドロコロイドシン ポジウム要旨集

5 ) 今井悦子 (2000): 口腔内粒子感覚と食品特性, 日本調理科学会 誌, 33, 76-81.

6 ) 沢村信一・原口康弘·池田博子・園田純子 (2010) : 粉砕方法の 異 なる抹茶の物性と形状, 食科工, 57, 304-309.

7 ) 大西市造・森本孝子・富樫佳泰 (1973) : てん茶の粉砕方法とまっ 茶の物性, 茶研報, No.39, 23-28 